UDC 618.3-06:616.9]-084

DOI: 10.21668/health.risk/2016.4.14.eng

\title{
MEDICAL AND SOCIOLOGICAL EXPLICATION OF THE PROBLEM OF INFECTIOUS DISEASES PROPHYLAXIS AMONG PREGNANT WOMEN
}

\author{
N.B. Merzlova ${ }^{1}$, I.A. Serova ${ }^{1}$, A.Yu. Yagodina ${ }^{2}$ \\ ${ }^{1}$ Perm State Medical University named after E.A. Wagner, 26 Petropavlovskaya Str., Perm, 614990, Russian Federation \\ ${ }^{2}$ Perm City Outpatient Clinic, 45 Permskaya Str., 614000, Perm, Russian Federation
}

The research is focused on revealing the TORCH-infections prophylaxis problems during preconception period and culture of personal infection safety among pregnant women. The research involved 2060 women. Epidemiological monitoring was accompanied by a social survey of the Perinatal Center patients using the continuous sampling method. The problems of the population's response adequacy regarding the dangers of TORCH-infection are presented on the basis of questionnaire survey of 55 pregnant women - patients of the Perinatal Center. Sociological explication of the problems of TORCH-infections prophylaxis revealed the positive and negative behavioral stereotypes of the Perm Region population from the point of view of assuring the personal infection safety. The positive stereotypes include cleanliness and vitamin prophylaxis practice. The regional hygienic culture can be developed by increased involvement in sport, immunological prophylaxis propaganda, safe sex, helminth prophylaxis in pets and regular tooth brushing. The survey has explicated the common negative behavour stereotypes leading to toxoplasmosis contamination during pregnancy. Only a half of the surveyed women avoid the intake of meat that did not undergo sufficient heat treatment, $72.7 \%$ of respondents cannot be relieved from the duties of cleaning the cat's toilet. The rating made on the basis of the survey concerning the popularity of measures assuring personal infection safety has shown a neglectful attitude of population towards the immunological prophylaxis and modern medical products affecting the immune system, that inevitably leads to problems with compliance of pregnant women to vaccination and immunological correction by immune modulators during treatment of the revealed infectious diseases. We found a mismatch between the behavioral stereotypes of the Perm Region population in ensuring personal infection safety and the academic principles of TORCH-infections prevention, that shows a persisting danger of vertical TORCH-infections transmission and requires efforts aimed at increasing the expertise of the population in TORCH-infections prophylaxis during preconception period.

Key words: TORCH-infections, infection safety, behavioral stereotypes, pregnancy infections, vertical infection transmission route, vaccination, immunological correction.

If we want to personify risks related to providing infectious safety during pregnancy, labor, and newborns nursing, we should be aware that this problem has three aspects, namely, medical one (infection risk and risk of infectious diseases evolving); economic one (costs of vaccination prevention, laboratory diagnostics, costs of nursing and social rehabilitation of newborns with grave infectious pathology); humanitarian one (safe nutrition stereotypes and safe behavioral stereotypes). Risks occur due to uncertainty and inability to see the future. If we model the future we can achieve mental decrease in risk level and thus make our anxiety level also lower. Being competent in providing personal infectious safety is a means of infectious and parasitic diseases prevention, and such prevention decreases both risk of transferring infection / invasion agents and risk of a disease evolvement.

(C) Merzlova N.B., Serova I.A., Yagodina A.Yu., 2016

Nina B. Merzlova - Doctor of Medical Sciences, Professor, Head of the Hospital Pediatrics Department (email: nmerzlova@yandex.ru; tel.: +7 (342) 221-86-15).

Irina A. Serova - Doctor of Philosophy, Professor, Professor of the Philosophy and Biological Ethics Department (e-mail: berrymoor@perm.ru; tel.: +7 (342) 281-74-81).

Anna Yu. Yagodina - Candidate of Medical Sciences, Infectiologist of the Primary Specialized Health Care Division (e-mail: annayagodina@ rambler.ru; tel.: +7 (342) 212-82-44). 
Which infections can exert negative influence on pregnancy? They are malaria, leptospirosis, and clamidiosis, as they lead to preterm labor and miscarriages. Cytomegalovirus infection (CMVI), toxoplasmosis, herpetic in- fection caused by HSV, rubella, chicken pox, and clamidiosis, exert negative influence on a newborn health. These infections can cause children malformations given in Table 1 .

Table 1

Children malformations caused by TORCH-infections

\begin{tabular}{|l|c|c|c|c|c|c|}
\hline \multicolumn{1}{|c|}{ Malformations } & $\begin{array}{c}\text { Toxoplasmo } \\
\text { sis }\end{array}$ & Clamidiosis & Rubella & CMVI & $\begin{array}{c}\text { Herpetic } \\
\text { infection }\end{array}$ & $\begin{array}{c}\text { Chicken } \\
\text { pox }\end{array}$ \\
\hline Brain damage (microcephalia) & & & & $*$ & & \\
\hline Brain damage (hydrocephalus) & $*$ & & & & & \\
\hline Deafness & & & & $*$ & & $*$ \\
\hline Rash & & & & $*$ & $*$ & $*$ \\
\hline Eyes damage (chorioretinitis) & $*$ & & & $*$ & $*$ & $*$ \\
\hline Multiple malformations & & & $*$ & & & $*$ \\
\hline Liver damage (hepatitis) & $*$ & & & $*$ & & $*$ \\
\hline Conjunctivitis & & $*$ & & & & \\
\hline Pneumonia & & $*$ & & & & \\
\hline
\end{tabular}

Toxoplasmosis, clamidiosis, rubella, CMVI, all so-called TORCH-infections can often have no symptoms in pregnant women but they cause fetus malformations. Some infections can be transferred from a mother to a child and infect it, for example, with HIVinfection, viral hepatitis B and C.

What are the main ways of transferring infections which are dangerous during fertility? Toxoplasmosis can be caught at eating raw minced meat or poorly roasted meat, and at cleaning up cats' toilets. CMVI and HSV are droplet infections and can be caught through kisses, talks at close distance, and in a sexual intercourse. Chicken pox and rubella can be caught only in a droplet way while hepatitis B and $\mathrm{C}$ and HIV infections are transferred via sexual contacts and parenteral way.

Vaccination is a preventive measure against hepatitis $\mathrm{B}$ and rubella. Prevention measures against CMVI, HSV, and chicken pox include having no contacts with small children during pregnancy, keeping away from pre-school children facilities and children polyclinics.

M.Yu. Surmach [8] proved, that if a level of a woman' prevention activity during pregnancy was low, it had negative influence on a newborn health. In particular, it was detected that $\%$ of intrauterine infections among women who fully completed pregravid preparation was substantially lower than among those who didn't get themselves ready for pregnancy at all $(0.2 \%$ against $4.6 \%$ correspondingly).

Our research goal was to reveal problems existing in TORCH-infections prevention during pregravid preparation. Application of sociological techniques in order to determine personal infectious safety culture among pregnant women being elements of epidemiologic process helps to analyze safety measures against TORCH-infections vertical contagion used in private life. Our research goal was to define how competent our population were in TORCH infections prevention issues.

Practical value. New data which we obtained on self-preserving behavior of the region population can be applied in implementing Perm region state program "Health care development" (Subprogram 1 "Diseases prevention and formation of healthy lifestyle. Development of primary medical and sanitary aid" and Subprogram 4 "Health protection for a mother and a child"). In particular, if we realize that population awareness is low it will help to reduce prevalence of significant factors causing diseases risks (Task 5 in Subprogram 1); if we optimize diseases prevention strategies it will lead to improvements of mothers' health (task 2 in Subprogram 4). 
Patients and techniques. Since 2001 all pregnant women in Perm region have been examined in order to detect TORCH-infections during observation over pregnancy. Most pregnant women receive their examination results in perinatal center of State Budgetary Healthcare Establishment "MSCH No.9 named after M.A. Tverjie". We performed retrospect research on TORCH-infections prevalence among pregnant women in this perinatal center from June 2010 till December 2013. Our research comprised 2,600 women [5]. epidemiological monitoring conducted during all March 2013 was combined with sociological questioning among perinatal center patients via universal sampling technique. Problems related to how relevantly our population reacts to dangers represented by TORCH-infections are highlighted in the results of questioning comprising 55 pregnant women - perinatal center patients. This questioning enabled us to determine personified respondents' attitudes towards infectious safety during pregnancy and preparation to it.

Results and discussion. The conducted questioning aimed at examining behavioral peculiarities of pregnant women revealed there were information problems in intrauterine infections prevention. Only $14.2 \%$ respondents gave correct answers to a question "What infections can have negative influence on pregnancy since they can cause preterm delivery or miscarriage?". But the next question, "What infections can lead to malformations?", caused less puzzlement and 56\% pregnant women gave correct answers. We should note that incorrect answers to the first question (54.5\%) were mostly due to high degree of phobia which exists in respect to HIV-infection and hepatitis and as for other infections and invasions they are considered to be quite curable [3].

Questioning results allowed us to draw up a popularity rating for measures aimed at providing personal infectious safety (Table 2) which confirmed the existing behavioral stereotypes of Perm region population as it coincided with the preferences which we had revealed a year before [4]. It is obvious that a lot is to be done in developing hygienic culture of the region population and the tasks include greater involvement of the population in sports, immunoprophylaxis propaganda, propaganda of safe sex, and prevention of helminthes in pets.

Popularity rating for measures aimed at providing personal infectious safety

\begin{tabular}{|c|c|c|}
\hline $\begin{array}{l}\text { No. } \\
\text { in rating }\end{array}$ & Measures aimed at preventing infectious and parasitic diseases & $\begin{array}{l}\text { Quantity of positive answers } \\
\text { in } \%\end{array}$ \\
\hline 1 & Wash my hands thoroughly & 92 \\
\hline 2 & Wash berries, fruit and vegetables thoroughly & 84 \\
\hline 3 & Take vitamins & 73 \\
\hline 4 & $\begin{array}{l}\text { Don't eat raw or insufficiently heat-treated meat and fish (raw frozen fish, dried fish, raw } \\
\text { minced meat, river fish caviar which was prepared at home) }\end{array}$ & 73 \\
\hline 5 & Follow all rules and terms of food staffs keeping & 71 \\
\hline 6 & Try to avoid contacts with sick people & 68 \\
\hline 7 & Don't gnaw my nails & 64 \\
\hline 8 & Brush my teeth twice a day & 61 \\
\hline 9 & Drink only boiled water & 61 \\
\hline 10 & Wear gauze bondages during flu epidemic & 36 \\
\hline 11 & Have only safe sex & 33 \\
\hline 12 & Use oksolin (naphthalene-1,2,3,4) ointment & 31 \\
\hline 13 & Apply prevention measures to protect my pets from helminthes & 21 \\
\hline 14 & Do sports & 19 \\
\hline 15 & Have vaccination against tick-borne encephalitis & 15 \\
\hline 16 & Have vaccination against hepatitis B & 15 \\
\hline 17 & Have vaccination against rubella & 14 \\
\hline 18 & Have vaccination against flu & 12 \\
\hline 19 & Add biological additives to my food & 7 \\
\hline 20 & $\begin{array}{l}\text { Take immune modulators (eleutherococcus tincture, ginseng tincture, cycloferon, panav- } \\
\text { ir) }\end{array}$ & 5 \\
\hline
\end{tabular}


Questioning revealed there were behavioral stereotypes providing toxoplasmosis prevention during pregnancy. $96.3 \%$ respondents answering the question "Which additional preventive measures against infectious and parasitic diseases are necessary during pregnancy?" told it was necessary to completely exclude raw minced meat and poorly heat-treated meat from the ration; $61.8 \%$ thought it necessary to "delegate" cleaning up cats' toilets to someone else in the family. However, the next question, "Which of the measures you've just mentioned do you personally implement in your everyday life?", revealed that only half of the respondents really didn't eat insufficiently heat-treated meat. As for taking care of pets, even smaller number of pregnant women complied with their own attitudes; $72.7 \%$ of them couldn't get rid of cleaning up cats' toilets. Half of the respondents had cats in their families and only $14.5 \%$ of the questioned pregnant women followed their hygienically justified attitudes towards toxoplasmosis prevention in their everyday life.

Carelessness in respect to toxoplasmosis prevention is determined by population unawareness about main child malformations [1] which can be caused by this invasion; according to our questioning results only $9.6 \%$ were aware of a newborn hydrocephalus risk, only $9 \%$, chorioretinitis risk, and $3.6 \%$, hepatitis risk, correspondingly.

History of acute toxoplasmosis treatment proves that treatment period tends to become longer, and set and doses of taken drugs increase. Recent multi-centered research highlighted the issues of treatment efficiency during pregnancy $[9,10]$. Levels of infection transferring from a mother to a child in groups receiving only spiramycin, pyrimethaminum, sulfadiasinum, folic acid or pyrimethaminum, sulfadiasinum with spiramycin or another atypical treatment didn't have any substantial discrepancies [12]. Chemotherapy doesn't provide full sanation of a body from the agent as it settles inside cells in tissues and it is difficult to affect it with drugs.

Alternative views on toxoplasmosis treatment efficiency during pregnancy make researchers look for compromise treatment. For example, monthly examination of pregnant women allows to make a period during which treatment starts a bit shorter. Amniotic fluid examination with the use of polymerase chain reaction helps to exclude a fetus infection and thus makes it unnecessary to take sulfadiasinum or pyrimethaminum during pregnancy [11]. As there is no consensus in respect to toxoplasmosis treatment principles prevention issues become really vital. Toxoplasmosis prevention principle for pregnant women is determining serological status in each woman who is going to conceive in order to detect infected ones and to provide others with information on how this invasion can be caught. In our opinion, principle of personal responsibility which a mother has for her child safety is the most efficient one; this principle means complete and strict prohibition on eating raw meat and on cleaning up a cat's toilet during pregnancy.

Droplet way of catching CMVI, HSV, chicken pox, and rubella, causes objective difficulties in these infections prevention and raises rhetorical questions: should we really explain a pregnant women that it is necessary to avoid contacts with small children, intimate talks or kisses during her pregravid period? Should we explain how to solve a dilemma between safe sex and conception? The only thing which is certain about prevention of droplet TORCH-infections is obligatory vaccination against rubella. It is also necessary to get vaccinated against measles during preparation to pregnancy. If you had vaccination from diphtheria and tetanus 10 years ago it is advisable to have re-vaccination.

Epidemic situation concerning hepatitis B in many regions is also an argument for immunoprophylaxis. We'd like to note that vaccination occupies next to last places in popularity rating for measures aimed at providing personal infectious safety according to our questioning. Only $27.2 \%$ respondents get vaccinated against tick-borne encephalitis and hepatitis $\mathrm{B} ; 25.4 \%$, against rubella; $21.8 \%$, against flu. And we should point out that pregnant women who are contact as per hepatitis B 
and who don't have detected HbsAg ought to be vaccinated against hepatitis B. It is very useful to inform women that most vaccines can be dangerous for a fetus only in theory. So, if a real risk to catch diphtheria, tetanus, hepatitis $\mathrm{A}$ and $\mathrm{B}$, flu, or poliomyelitis, exists, it is quite possible to get vaccinated during pregnancy.

In addition to immunoprophylaxis we can find other spheres which were detected in the course of our questioning and where personal protection of population from infection risk can be improved. For example, talks on immune deficiency of various etiology can be very productive as we can treat it as a target for TORCH-infections prevention during period of preparation to pregnancy [2]. Traditional neglectful attitude (confirmed also by our questioning) towards immune modulators may need revision. Why taking vitamins is on the third place in popularity rating for measures aimed at providing personal infectious safety, and taking immune modulators occupies the last one? Is this population behavioral stereotype consistent with scientific research results? For example, V.N. Prilepskaya, A.V. Ledina and N.A. Korotaeva in their article analyze the results of a snap clinical multi-centered controlled research of Panavir drug safety and tolerance for pregnant women during II and III trimester [7]. It was detected that if Panavir drug was included into complex therapy of CMVI acute condition it efficiently resulted in reduction in titer of immunoglobulin $G$ and prevented newborns' infection; it was safe both for a mother and a fetus; it didn't have any side effects and didn't lead to unwanted consequences. Immune modulators are also widely used to prevent herpetic infection recurrences. Neglectful attitude of population towards immunoprophylaxis as well as towards modern drugs influencing immunity which we detected unavoidably leads to problems of pregnant women' compliance with vaccination and immunocorrection with immune modulators in case of detected infectious diseases (CMVI, HSV).

Sociological explication of medical problems can have no purpose and serve only as a supplementary research product in various perspectives detecting population behavioral stereotypes. Sociologists most frequently register features of moral status which medical organizations have; features of moral attitude which doctors and patients have; features of ethical relationships culture in medicine [6]. In our opinion, sociology can be efficient in solving specific medical problems, particularly, problems of patients' compliance with treatment. Medical-sociological questionings during visits to a doctor obviously perform prevention tasks via sanitary-hygienic education and have a positive influence on self-preserving behavior of region population.

Conclusion. We detected inconsistence between behavioral stereotypes of Perm region population in the sphere of providing personal infectious safety and academic principles of TORCH-infections prevention. It means there is still a danger of TORCH-infections vertical contagion and some efforts are required which will increase population awareness as regards TORCH-infections prevention during pregravid preparation.

\section{References}

1. Barycheva L.Yu., Golubeva M.V., Kabulova M.A. Poroki razvitiya u detei s vrozhdennymi tsitomegalovirusnoi i toksoplazmennoi infektsiyami [Malformations in children with congenital cytomegalovirus infections and congenital toxoplasmosis]. Sovremennye problemy nauki i obrazovaniya, 2014, no.1, pp. 150 (in Russian).

2. Dolgikh T.I. Toksoplazmoz: sovremennaya strategiya laboratornoi diagnostiki [Toxoplasmosis: modern strategy of laboratory diagnostics]. Infektsiya i immunitet, 2011, vol.1, no.1, pp. 43-50 (in Russian).

3. Merzlova N.B., Serova I.A., Yagodina A.Yu. Klassifikatsiya infektsionnykh i parazitarnykh boleznei po sotsiologicheskim kriteriyam [Classification of infectious and parasitic diseases in accordance with sociological criteria]. Meditsinskaya parazitologiya i parazitarnye bolezni, 2011, no. 2, pp.3539 (in Russian). 
4. Merzlova N.B., Serova I.A., Yagodina A.Yu. Etologicheskaya kompetentnost' zhitelei Permskogo kraya $\mathrm{v}$ obespechenii personal'noi infektsionnoi bezopasnosti [Ethological expertise of the Perm Region population in assuring personal infection safety]. Meditsinskaya parazitologiya $i$ parazitarnye bolezni, 2014, no. 2, pp. 22-25 (in Russian).

5. Merzlova N.B., Serova I.A., Yagodina A.Yu. Aktual'nye printsipy diagnostiki, lecheniya i profilaktiki toksoplazmoza pri beremennosti [Up-to-date principles of diagnosis, treatment and prevention of toxoplasmosis during pregnancy]. Meditsinskaya parazitologiya i parazitarnye bolezni, 2015, no. 3, pp. 13-17 (in Russian).

6. Navrotskii B.A., Delaryu V.V. Problemy bioetiki v sotsiologicheskikh issledovaniyakh gorodskoi tematiki [Problems of bioethics in sociology city themes]. Bioetika, 2014, no. 1, pp. 31-33 (in Russian).

7. Prilepskaya V.N., Ledina A.V., Korotkova N.A. Tsitomegalovirusnaya infektsiya: vozmozhnosti terapii vo vremya beremennosti [Cytomegalovirus infections: therapeutic potential in pregnancy]. Ginekologiya, 2014, vol.16, no. 3, pp. 35-37 (in Russian).

8. Surmach M.Yu. Reproduktivnoe povedenie molodezhi Belarusi i ego determinatsiya [Reproductive behavior of Belarusian youths and its determination Part 2. Planning of pregnancy in young age and influence of woman's behavior on the newborn's health. Medical-hygienic literacy as an anti-risk factor]. Zhurnal Grodnenskogo gosudarstvennogo meditsinskogo universiteta, 2011, vol. 36, no. 4, pp. 32-35 (in Russian).

9. Li X.L., Wei H.X., Zhang H., Peng H.J., Lindsay D.S. A Meta Analysis on Risks of Adverse Pregnancy Outcomes in Toxoplasma gondii Infection. PLoS ONE, 2014, vol. 9, no. 5, pp. e97775. doi:10.1371/journal.pone.0097775

10. Wallon M.L., Peyron F., Cornu C., Vinault S., Abrahamowicz M., Kopp C.B., Binquet C. Congenital toxoplasma infection: monthly prenatal screening decreases transmission rate and improves clinical outcome at age 3 years. Clin Infect Dis, 2013 May, vol. 56, no. 9, pp.1223-1231.

11. Baquero-Artigao F., del Castillo Martín F., Fuentes Corripio I., Goncé Mellgren A., Fortuny Guasch C., de la Calle Fernández-Miranda M., Gonz lez-Tomé M.I., Couceiro Gianzo J.A., Neth O., Ramos Amador J.T. Grupo de Trabajo de Infección Congénita y Perinatal de la Sociedad Española de Infectología Pediátrica (SEIP). The Spanish Society of Pediatric Infectious Diseases Guidelines for the diagnosis and treatment of congenital toxoplasmosis. An Pediatr (Barc), 2013 Aug, vol.79, no. 2, pp. 116.

12. Garcia-Méric P., Franck J., Dumon H., Piarroux R. Management of congenital toxoplasmosis in France: current data. Presse Med, 2010, vol. 39, no. 5, pp. 530-538.

Merzlova N.B., Serova I.A., Yagodina A.Yu. Medical and sociological explication of the problem of infectious diseases prophylaxis among pregnant women. Health Risk Analysis, 2016, no. 4, pp. 118 123. DOI: 10.21668/health.risk/2016.4.14.eng

Received: 29.08.2016

Accepted: 13.12 .2016

Published: 30.12 .2016 